\title{
The Impact of Changes in Oil Price on Stock Market: Evidence from Africa
}

\begin{abstract}
Ikechukwu Kelikume ${ }^{1}$
${ }^{*}$ Omotayo Muritala ${ }^{1}$



The impact of crude oil price on stock markets has continued to attract attention from researchers and investors from theoretical and empirical angles; from sectoral, country-specific, regional and global analyses (Dutta, Nikkinen and Rothovius, 2017; Ftiti, Guesmi and Abid, 2016; Hamdi et al., 2019; Hu et al., 2018; Huang et al., 2017; Ji et al., 2018; Kang, de Gracia and Ratti, 2017; Luo and Qin, 2017; Tursoy and Faisal, 2018; Wong and El-Massah, 2018; Xiao et al., 2018; Zhu et al., 2016). The increasing attention has likened the importance of crude oil as a standard product in many sectors of the world's economy (Gourène and Mendy, 2018). Oil is a common source of fuel, and it accounts for 39.9 percent of the world fuel consumption (IEA, 2016), despite the rising efforts at renewable and alternative energies, crude oil consumption remains unaffected (Gourène and Mendy, 2018).

The increasing theoretical and empirical inquiry into the relationship between crude oil prices and stock markets indicates the importance of crude oil to the world economy through its impact on corporate liquidity and earnings (Badeeb and Lean, 2018). From the theoretical perspective, the equity valuation theory explains that "stock price is the sum of the discounted values of expected future cash flows at different investment horizons", which is dependent on macroeconomic economic conditions 
International Journal of Management, Economics and Social Sciences

such as interest rate, inflation, production cost, aggregate demand and investors' confidence (Arouri, Jouini and Nguyen, 2012; Badeeb and Lean, 2018). Crude oil price shocks affect the stock markets through their influences on monetary policy instruments, inflation, corporate income and other economic activities (Gourène and Mendy, 2018) in both developed and emerging economies.

In the past four decades, several African countries (Nigeria, Angola, Algeria, Egypt, Libya, Gabon, Chad, DR Congo, Ghana, Ivory Coast, Senegal, and South Africa) have emerged as oil-producing countries at the global or regional levels. Thus, Africa plays a significant role in crude oil production than use. Hitherto, the founding of African Petroleum Producers' Association (APPA) in 1987 as an institution that aids the sharing of knowledge and expertise for all African oil producers reflects the influence of oil market in African economies (Gourène and Mendy, 2018).

The dynamics of oil have several implications from both demand and supply sides. Previous empirical studies (Ewing and Thompson, 2018; Herwartz and Plödt, 2016; Huntington, 2007; Jain and Biswal, 2016; Ju et al., 2016; Kilian, 2008; Kumar and Goh, 2019; Lee, Ni and Ratti, 1995; Mork, 1989; Mendoza and Vera, 2010; Raymond and Rich, 1997; Ratti and Vespignani, 2016) employed various macroeconomic variables such as gross domestic product/total national product, industrial production, inflation, interest rate, and income. Also, other empirical studies on oil price shocks and stock markets responses are focused mainly on developed economies at the expense of emerging markets (e.g., An et al., 2018; Diaz, Molero and de Gracia, 2016; Hamdi et al., 2019; Hu et al., 2018; Tursoy and Faisal, 2018). Diaz et al. (2016) studied the oil price volatility and stock returns nexus in the G7 economies (Canada, France, Germany, Italy, Japan, the UK and the US) and reported a negative relationship between world oil price volatility and stock returns using the vector autoregressive method. Tursoy and Faisal (2018) were only interested in the Turkish economy when they investigated the impact of crude oil price on stock prices. Their result following the autoregressive distributed lag (ARDL) analysis established the existence of a positive relationship between crude oil price and stock prices. Their findings depart sharply from those of Diaz et al. (2016). Also, An et al. (2018) concentrated on the oil-stock co-movement in the Chinese economy while Hamdi et al. (2019) focused on the Gulf Cooperation Council.

Surprisingly, among the studies on developing economies, Africa has not been a focal point (see Al-hajj, Al-Mulali and Solarin, 2018; Ji et al., 2018; Wong and El-Massah, 2018; Zhu et al., 2016), and the few studies on Africa (see Asaolu and Ilo, 2012; Aye, 2014; Gil-Alana and Yaya, 2014; Gupta and Modise, 2013; Lin, Wesseh and Appiah, 2014; Gourène and Mendy, 2018) are deficient in scope and methodology. For instance, the study conducted by Asaolu and Ilo (2012) analyzed the relationship between the stock market and oil price in Nigeria between year 1987 and 2007 using the cointegration technique. Lin et al. (2014) studied the nexus between oil price and the Ghanaian stock 


\section{Kelikume \& Muritala}

market. Gupta and Modise (2013) were interested in the oil-stock analysis for South Africa using the structural vector autoregression (SVAR) approach. These studies ignored the whole African perspective by following a country-specific dimension instead of a panel approach. However, Gourène and Mendy (2018) focused on six African countries but adopted the wavelet analysis to examine the oil-stock nexus. The wavelet coherence analysis faces weak assumptions about the data series, lack of functional process, indefinite choice of wavelet, and does not handle asymmetry and orthogonal problems (He and Nguyen, 2015). Furthermore, the practical tools for data analysis are co-integration and vector autoregression. The former focused on long-run co-movement without impact consideration, and the latter examines long-run dynamics without short-run analysis. Thus, policy implications based on these approaches are seldom relevant in investment decisions in Africa. This is because most investors in the African stock markets are interested in the short-run rather than longrun analysis of stocks due to high volatility occasioned by political unrest, social upheavals, policy reversal, and market fragmentation (Panda, Nanda \& Paital, 2019).

Therefore, this article seems prudent as it complements a growing literature on the oil-stock research space. The purpose of this article is to determine the impact of crude oil price shocks on the most active African stock markets and to elicit other macroeconomic parameters that drive stock market performance in the African continent. The study's contribution to knowledge is fourfold. First, it extends the work of Gourène and Mendy (2018) by focusing on the most active stock markets of oilexporting countries in Africa. This study made strong assumptions about the data series. Secondly, the investigation makes use of a panel data analysis which provides more robust findings compared to country-specific studies. The panel analysis through the power of tests increases the precision of estimators, and by the way, provides inferences that are more reliable. Third, the study evaluates the model using dynamic ordinary least square methods and makes comparisons with ordinary least squares estimators. Fourth, this study contributes to the controversy and debate on the oil-stock nexus and its policy implications, which could assist capital market investors and fund managers in portfolio diversification, risk management and inflation hedging in the volatile and fragmented African stock market.

The rest of the paper is structured as follows. Section 2 presents the literature review and explores previous studies on the oil-stock market relationship. Section 3 discusses the methodology employed in the study. Section 4 reports the finding of the study, while part 5, 6 and 7 provide conclusion, implications, and limitations/future directions, respectively.

\section{LITERATURE REVIEW}

Studies on crude oil price-macroeconomy nexus originated from the developed economies and grad- 
ually trickled down to emerging markets, with a few on the African continent. Pioneering studies include Burbidge and Harrison (1984) and Gisser and Goodwin (1986). Burbidge and Harrison (1984) conduct an investigation similar to Hamilton (1983) but with data obtained for five OECD countries. A significant impact of rising oil price on real outputs is found at varying degrees for the study countries, namely the US, UK, Canada, Japan, and Germany. The study by Gisser and Goodwin (1986) serves as a further investigation on crude oil price-macroeconomy nexus in the US. Although the authors found strong evidence for a significant impact of oil prices on the US macroeconomy, there is a lack of functional relationship between crude oil prices and macroeconomy-oil prices and the outputs maintain a stable relationship over the study period 1961 to 1982. Generally, the empirical studies employ multivariate models of oil prices and important macroeconomic measures such as price level, output, employment growth, exchange rate, investment.

Studies conducted by Sadorsky (1999) and Papapetrou (2001) show that oil prices and stock markets are negatively correlated. The first two studies are based on aggregated stock data, and the studies employed a multivariate vector autoregression approach. Using monthly data for the US economy, Sadorsky (1999) examined the impact of oil price shocks on market returns and two other key macroeconomic measures-industrial production and interest rate. The findings show that positive oil price shocks affect real stock returns and a more significant fraction of the forecast error variance in stock returns is credited to movements in oil prices rather than the interest rate. The study by Papapetrou (2001) on Greece economy yields interdependence between oil and stock data and a significant impact of oil price. This provides evidence for positive oil price shocks reducing real stock returns. Similarly, Rafailidis and Katrakilidis (2014) also found that oil prices and stock returns are negatively correlated.

In the literature, considerable advancement has been made in the aspect of methodology. Most earlier studies are based on the conventional cointegration approach that examines relationships between changes in oil and stock prices, and a multivariate vector autoregression merely to determine if and how volatility transmits from one market to another and the possible feedback effect in lead-lag scenarios. According to Zhu et al., (2011), accounting for asymmetry in stock data analysis yields robust inferences. Ghosh and Kanjilal (2016) proved this when they investigated co-movements of crude oil price and Indian stock market by testing a non-linearity threshold cointegration (Gregory and Hasen, and Hatemi-J tests) for an aggregated and disaggregated data in three phases. The study finds no cointegrating relationship for the entire data set, but a cointegrating relationship in phase III of sub data set. The existence of a long-run relationship in the sub data set implies asymmetric transmission in shocks from oil price to the stock market. Narayan and Narayan (2010) are one of the early adopters of structural break estimation techniques. The study models the relationship between oil 


\section{Kelikume \& Muritala}

and stock prices for Vietnam. The authors provide strong evidence of a positive statistically significant long-run effect of oil price on the stock market - a percentage rise in oil price increases the stock price by 1.3 percent. Also, the report of Zhu et al.'s (2011) supported the position of Arouri and Rault (2009) by deploying a bootstrap panel cointegration and indicates shocks in oil price have a positive effect for UAE, Qatar, Oman, Kuwait, and Bahrain, and no significant impact of oil shocks for Saudi Arabia. Generally, the co-integration approach tends to support the long-run relationship between oil price and stock market indicator. This method does not consider short-run relationship and it is only required when the variables are differently integrated or have different orders.

A perusal of literature reveals that other studies employ the least square regression technique to analyse the oil price and stock market relationship. In a country-specific study conducted by Soyemi, Akingunola and Ogebe (2017) applying the three-stage least squares technique on data series between 2007 and 2014, the results of the study revealed that oil shocks have a significant positive effect on company stock returns in Nigeria. Xiao et al. (2018) examined the effects of oil price uncertainty on the aggregate and sectoral stock returns in China. The study, which employs the quantile regression approach, and finds that oil price volatility exerts significant adverse effects on the total and sectoral stock returns when the market is bearish. This sharply depart from earlier findings of Zhu et al. (2016) for China which found a significant positive effect of crude oil price on industrial sector stocks returns using the quantile regression approach. In a more recent investigation, Hamdi et al. (2019) inquire the effects of volatility in oil price on sectoral indices in the Gulf Cooperation Council (GCC) countries based on quantile regression analysis between 2006 and 2017. The study's empirical results indicate that all the economic sectors are responding to oil price volatility except for the banking, insurance, transport and telecommunication sectors. While the banking and insurance sectors are insusceptible during the $10^{\text {th }}, 25^{\text {th }}$ and $75^{\text {th }}$ quantiles, the transport and telecommunication sectors are unaffected by volatility in oil prices during $75^{\text {th }}$ and $90^{\text {th }}$. It is obvious that the results from the various types of the least square analysis support the existence of an adverse effect of oil price shocks on economic activities in both advanced and emerging economies, which is a sharp departure from the evidence presented using the cointegration approach. However, the divergence in result could be justified by the fact that the latter method considers only a short-run relationship as against the former which captures long-run associations. As empirical evidence continued to generate intense debates on the nature of relationship between oil price and stock market, researchers have devised improved methodology to intelligently contribute to the debate. It is in the light of the above that the vector autoregression technique, wavelet and non-linear autoregressive distributed lag model were employed by other studies.

Ono (2011) studies the response of stock returns to oil shock for BRICs in a vector autoregression 
model. A significant positive response is found for all the countries except Brazil. Salisu and Oloko (2015) deploy the vector autoregression moving average-asymmetric generalized conditional heteroscedasticity (VARMA AGARCH) model with a modification that includes endogenously determined structural break (in estimating returns), volatility, shock spillover, and own-market and cross-market asymmetric effects, for oil price and US stock market. The authors found strong evidence for a bi-directional shock spillover from the two markets, a cross-market asymmetric shock spillover, and volatility spillover from oil market to stock market in the pre-break, however, the impact of volatility spillover from oil market to stock market was evident in the post-break period. Their study proved that the effects of oil price on the stock market under different economic conditions lack consistency. Similarly, Diaz et al. (2016) explore the co-movement between oil price volatility and stock returns in the G7 economies using monthly data for the period from 1970 to 2014. The evidence from the vector autoregressive model analysis supports the existence of an inverse relationship between oil price volatility and stock market performance. Also, the world oil price volatility has a more significant negative impact on stock markets than the national oil price volatility. Ding et al. (2017) examine the contagion effect of global oil price volatility on the investor's sentiment in China using the structural vector autoregression approach. The empirical evidence shows that world crude oil price fluctuations significantly Granger caused Chinese stock market investor sentiment in both the short-run and long-run. On a micro level, Kang et al. (2017) investigate the impacts of oil price shocks on the stock returns of oil and gas companies using the vector autoregression model. The empirical result suggests that an oil demand-side shock has a positive effect on the performance of oil and gas companies, while shocks to policy uncertainty impacts negatively on stock returns. The variance decomposition shows that the endogenous policy uncertainty responses propel the impact of oil shocks on the stock return. Lending credence to the oil price and stock markets interdependence, Wong and El-Massah (2018) study the effects of oil price changes on Gulf Cooperation Council stock markets between 2005 and 2015. Using the Granger causality and impulse response techniques, the result of the study showed a significant negative impact from oil price fluctuations on the GCC stock markets. From the vector autoregression perspective, oil price has predominantly exhibited a negative impact on stock returns. The VAR technique requires that all variables be integrated in first difference, which may not be obtainable. This has led to the adoption of combined techniques for the purpose of comparison, robustness and reliability.

Ftiti et al. (2016) investigate the co-movement between oil and the stock markets in G7 economies and distinguish between interactions based on fundamentals (long-term interdependence: high memory impact) and contagion (short-term relationship: transitory contamination). The study employs the wavelet and dynamic correlation approaches and reports that the interrelationship between oil price 


\section{Kelikume \& Muritala}

and the stock market which is evident in the short and medium terms than in the long-run. Also, the study proved that stock markets are more sensitive to oil shocks originating from demand shocks. Huang et al. (2017) explored the dynamic relations between the oil price volatility, and stock market returns to determine whether oil price could exert asymmetric effects on the stock market. The study used the wavelet analysis and vector autoregression approaches and affirms that for each time horizon, oil price fluctuations have a significant impact on the stock returns. Also, the result documented that the stock market has a backward linkage to the oil price. Further evidence supports the position that response amplitude of the stock market to changes in the oil price increases as the time horizon lengthens with varying response direction across different time horizons. Also, Luo and Qin (2017) studied the effects of oil price shocks and oil price volatility shocks on the Chinese stock market index and five sector returns. The study employed the wavelet and autoregression approaches and documents that oil price shocks positively affect Chinese stock returns. More importantly, evidence indicated that the oil price volatility shocks have significant and adverse effects on the Chinese stock market while the impact of realized volatility shocks is negligible, especially after the recent financial crisis. An et al. (2018) investigated the influence of Brent oil price fluctuations on the stock prices of the petrochemical block and the electric equipment and new energy block for China. The study employed the Shannon entropy of information theory, and the results revealed that both networks have different fluctuations characteristics in different periods. Their co-movement patterns clustered in some fundamental modes and conversion intermediaries. It also explains the lag effect of crude oil price fluctuations on the stock in Chinese industry blocks.

Gourène and Mendy (2018) investigate the relationship between oil prices and the six largest African stock markets using the wavelet coherence analysis. The study reports a low co-movement between oil prices and African stock markets except for South Africa and Egypt. Though this study concentrates on the African continents, its methodological relevance has come under severe attacks like other studies that employ the similar approach. Pal and Mitra (2019) investigate the interdependency between oil price and automobile stock return from August 01, 1996 to June 20, 2017, using the wavelet time-frequency domain analysis. The results of the study imply that the co-movement between oil price and automobile stock return is strong during November 2000 - December 2002 and March 2006 - December 2009, which is significant in the long-run from demand shock. The result holds excellent implications for investors in the automobile industry. Investors should not include oil asset in a portfolio of automobile stocks as crude oil does not offer a cushion against bearish automobile stock markets during the crisis period. The adoption of the wavelet coherence analysis implies weak assumptions about the statistical data employed, orthogonal issues and the problems of asymmetry. These challenges limit the robustness of studies that are based on wavelet analysis. These 
limitations prompted further methodological collaborations.

In a recent study for the Chinese oil-stock relationship, Hu et al. (2018) combined the Structural VAR model and the non-linear Autoregressive Distributed Lag (NARDL) model to determine the longrun and short-run asymmetric effects of structural oil price shocks on the Chinese stock market. The empirical results indicate that the demand-side shocks of oil price have a significant impact on the Chinese stock market in the short-run and long-run, while the supply shock does not. The study improved on the methodological dimension of previous studies by adopting the non-linear ARDL model to analyze the short-run and long-run relationships simultaneously. In a country-specific study, Tursoy and Faisal (2018) used the ARDL bounds cointegration, fully modified ordinary least square, and the dynamic ordinary least square to examine whether a long-run and short-run relationship exist amongst stock prices, gold prices and crude oil price for Turkey. The study used monthly time series data from January 1986 to November 2016. The empirical evidence showed a negative relationship between stock and oil variables in both short-run and long-run. The result of the Granger causality test indicates a short-run and long-run unidirectional joint causation from gold prices to stock prices. This implies that oil price volatility does not Granger causes stock prices; neither does the reverse hold for Turkey. In a panel analysis, Ji et al. (2018) explored the dynamic relationship and risk spillover between BRICS stock returns and oil shocks, using the combination of the Structural VAR model and time-varying copula-GARCH-based CoVaR approach. The empirical results revealed that the dependence between BRICS stock returns and oil shocks was unstable and dependent on the nature of the stock market. Essentially, the shape of the CoVaRs in each country is comparatively different, depending on its unique market situation and domestic policies. There is significant risk spillover from oil-specific demand shock to stock returns in all the BRICS countries. In Brazil, Russia and India, there is a significant asymmetric effect between upside and downside risk spillovers based on oil aggregate demand-shock and oil-specific demand shock. Al-hajj et al. (2018) studied how fluctuations in oil price, interest rate, exchange rate, industrial production, and inflation impact on the stock market returns for Malaysia. The study employs the non-linear autoregressive distributed lag (NARDL) to analyze monthly data covering the period between January 1990 to November 2016 and from May 2000 to November 2016 for the aggregate market and the nine sectors, respectively. The ARDL bounds test result indicates the existence of a long-run cointegrating relationship. In specific terms, oil price shocks negatively affect the stock market returns. The result shows that the Malaysian stock market is susceptible to crude oil price depreciation and appreciation.

The list of empirical studies on the oil-stock space is unending, (see studies Asaolu and Ilo, 2012; Basher, Haug and Sadorsky, 2018; Bastianin and Manera, 2018; Badeeb and Lean, 2018; Mikhaylov, 2018; Sharma et al., 2018; Singhal, Choudhary and Biswal, 2019; Wei and Guo, 2017), it is evident 


\section{Kelikume \& Muritala}

that the large number of studies are predominantly non-African-focused. However, of the few studies that focus on Africa majority are country-specific except for Gourène and Mendy (2018), which employ the wavelet analysis technique with several limitations, and that affect the robustness of the study's findings. This article provides a robust and straightforward methodological analysis of the oil-stock co-movement to guide prospective investors in Africa and African governments on policy direction.

The present study chooses to investigate the nexus between oil prices and stock returns in a panel model for five African countries, namely Egypt, Ghana, Nigeria, South Africa and Tunisia. The relationship is examined using both panel ordinary least square method (OLS) and dynamic panel ordinary least square (DOLS) for long and short-run effects based on the symmetric theory of Hamilton (1983).

\section{Theoretical Framework}

Theories provide the building blocks for empirical analysis in scientific research. Studies in the past have adopted different theories to underpin their analysis of the impact of oil price volatility on stock markets. For instance, An et al. (2018) adopted the Shannon Entropy Information Theory to analyze the oil-stock space for China, while Arouri et al. (2012) anchored their studies on the value of equity theory. In this study, the linear/symmetric theory of Hamilton (1983) which established the theoretical nexus between crude oil price and macroeconomic variables serves as the framework. The symmetric or linear theory was developed following the observed performance of the US economy with the rising oil prices in the post-world war II era. The evidence provided by the approach shows a strong correlation between oil prices and critical macroeconomic measures and proves why rising oil prices were responsible for every post-World War II recession except for 1960's depression. This theory has been validated by other earlier studies like Burbidge and Harrison (1984), and Gisser and Goodwin (1986). Burbidge and Harrison (1984) obtained data from five OECD countries (US, UK, Canada, Japan and Germany) and validated the Symmetric theory by documenting a significant impact of rising oil price on real outputs. From a country-specific analysis, the study by Gisser and Goodwin (1986) further investigated crude oil price-macroeconomy nexus in the US. Although the authors find strong evidence for a significant impact of oil prices on the US macroeconomy, there is a lack of functional relationship between crude oil prices and macroeconomy - oil prices and the outputs maintain a stable relationship over the study period 1961 to 1982. Generally, empirical studies employ multivariate models of oil prices and critical macroeconomic measures such as price level, output, employment growth, exchange rate, investment etc. as lay down by the symmetric theory of Hamilton. Thus, this study relates crude oil price to macroeconomic variables such as stock markets indicators and exchange rate, its theoretical underpinning is derived from Hamilton's symmetric theory. 


\section{METHODOLOGY}

-Data

This study analyzed quarterly data spanned Q1:2010 to Q4:2018 for five oil-exporting African nations namely, Nigeria, South Africa, Tunisia, Ghana, and Egypt. These constitute economies with active stock markets for which data is available. The timeframe covers the periods of low and high global oil prices, so, the effect of changes in oil price is well captured. In studying oil price effects on stock markets, this study makes use of stock market returns computed from the All-Share Index (Composite) for four countries, except Egypt where we have to use the MSCl Egypt Index (MSCI) accounts for 85 percent of the total Egyptian market equities). For oil price, the Organization of Petroleum Exporting Countries (OPEC) price, which is the reference basket of crude oil for OPEC members, is used. Stock price and exchange rate data were sourced for each country for the period reviewed. The stock and oil price data were sourced from Bloomberg database, while the exchange rate data were sourced from the International Financial Statistics (IFS) of the International Monetary Fund (IMF) and country's central bank website. The stock returns (SR) for the selected countries are calculated from all share index using the formula below:

$$
S R=\frac{\text { ending returns }- \text { starting returns }}{\text { starting retuns }}: 100
$$

Table 1 (see Appendix-l) contains the summary of descriptive statistics. The data reported a declined average stock return for all the five countries. Egypt, with a mean of 0.999, seems to have performed well, comparatively, Nigeria performed averagely with 0.526 , while Ghana and Tunisia with 0.475 and 0.487 , respectively, were the least performing countries in the group. The range is higher in countries that had a high average return, and vice versa except for Ghana which had the least average returns and the highest range. The countries recorded similar statistics for oil price since a standard OPEC basket price was adopted. The highest and lowest prices for the period are US\$117.630 (in 2012) and US\$31.190 (in 2016), respectively. The price reached its peak in Q1 2012 after which a decline set in, and by September 2014 the price was US\$ 95.98 and US\$ 31.1 in Q1 2016. The average price reported for the period is US\$ 78.788. Data on the exchange rate for Nigeria showed US\$203. 93 (an average rate for the period) which is higher than the rates in other countries. Equally, the difference between the highest and lowest exchange rates, about US\$156.616, shows that Nigeria seemed to have experienced high volatility compared to other countries such as Tunisia (US\$ 1.534), Ghana (US\$ 3.367), South Africa (US\$ 9.040) and Egypt (US\$ 12.45). The economic growth rate performance of the countries reveals that Ghana has the highest average growth rate of 


\section{Kelikume \& Muritala}

6.89 percent. Nigeria recorded 3.808 percent average quarterly growth rate within the period while Egypt, Tunisia and South Africa have respective RGDP growth of 3.65 percent, 2.05 percent, and 2.026 percent.

Figure 1, 2, 3, 4 and 5 (see Appendix-II) depict graphical illustrations of the relationships between international crude oil price and the stock prices of each of the countries under study. As illustrated, there happens to be a positive relationship between the oil price and each of the nation's stock market prices, except for Ghana, where there is significant volatility in the stock market.

\section{-The Model}

This study looks into the impact that oil price (OP) has on stock market returns (SR) in leading oil exporting nations in Africa. It starts with a bivariate model with the specification as:

$$
S R_{i t}=\alpha_{0}+\alpha_{1} O P_{i t}+\varepsilon_{i t}
$$

However, to omit variable biases, and to advance on related study in the literature, the exchange rate (EX) was introduced as a third variable. Following is the natural log form:

$$
\operatorname{lnSR}_{i t}=\alpha_{0}+\alpha_{1} \ln O P_{i t}+\alpha_{2} \operatorname{lnEX} X_{i t}+\varepsilon_{i t}
$$

The Exchange rate has its impact on stock yields through its effects on firm's competitiveness. Exchange rate depreciation for an import-dependent nation weakens the productive capacity of firms as a result of high production costs, invariably will have a negative effect on stock prices and their returns. While for an exporting nation, currency depreciation will boost the earnings of local firms, and invariably tell positively on their productivity, stock prices and returns. The appreciation of the exchange rate leads to low production cost for firms in import-dependent nations and boosts their production as well as increases their stock prices and returns. This however affects export-dependent firms, as earnings, stock prices, and returns fall.

\section{-Unit Root}

The Im, Pesaran \& Shin (IPS) and the Fisher-ADF unit roots tests are employed to ascertain the stationarity properties of the variables, which are more powerful when compared to the conventional time series stationarity unit root tests (Al-mulali and Sab, 2012). Both tests leverage on the individual Augmented Dickey-Fuller (ADF) unit roots tests.

The IPS follows the estimation model:

$$
\Delta y_{i t}=\alpha_{i}+\beta_{i}+\gamma_{t}+\theta_{i} y_{i t-1}+\sum_{j-1}^{\rho} \emptyset_{i, j} y_{i, t-j}+\mu_{i t}
$$




$$
\Delta y_{i, t}=\alpha_{i}+\beta_{i} t+\gamma_{t}+\theta_{i} y_{i, t-1}+\sum_{j=1}^{p} \varphi_{i, j} y_{i, t-j}+\mu_{i, t} .
$$

While the Fisher-ADF is based on:

$$
\Delta y_{t t}=\alpha y_{t t-1}+\sum_{j=1}^{p_{i}} \beta_{t j} \Delta y_{t t-j}+X_{i t}^{/} \delta+c_{t t} .
$$

They assume a normality distribution as the time and cross-sectional factors approaches infinity. The null hypothesis for these tests assumed that, for all cross-sectional units, the series has a unit root test. The alternative considered that it is stationary. Thus, their hypothesis can be stated as:

\section{$I I_{0}: \rho_{i}-0$ for all $i$.}

$H_{1}: \rho_{l}<0 \quad i=1,2,3 \ldots \ldots . .$.

$H_{1}: \rho_{i}=0 \quad i=N_{1}+1_{i} N_{1}+2, N_{1}+3, \ldots \ldots N$.

\section{-Cointegration Test}

Pedroni Panel cointegration is an advanced cointegration test that supersedes the traditional cointegration test (Al-mulali and Sab, 2012; Shahbaz et al., 2015), and an Engle-Granger based technique which also assumed the first-differenced stationarity of the involved variables, i.e., they are I (1). The test is based on the equation:

$$
x_{i, t}=\alpha_{i}+\rho_{i} t+\beta_{1 i} 7_{1 i, t} \ldots \ldots \ldots \ldots \ldots \ldots \beta_{m i} Z_{m i, t}+\mu_{i, t}
$$

Both the intercepts and slope values, i.e., $\alpha_{i}$ and the $\beta_{m i ' s}$ respectively, vary across the crosssectional levels of the panel. It is also assumed that the variables $X$ and $Z$ are first-differenced stationary, as a pre-condition to its estimation. The technique deploys seven test statistics grouped under Within-dimension statistics and Between-dimension statistics. All the seven test statistics assume a null hypothesis of no cointegration, i.e., $H_{0}: \rho_{i}=1 \forall i . \rho_{i}$ serves as the coefficient estimate of the residual. There are two alternative hypotheses based on the properties of the cointegrating vector $\beta_{i}$. The first alternative hypothesis is the panel statistics (within-dimension) states that $\beta_{i}$ has an homogenous property, i.e., $H_{1}: \rho_{i}=\rho<1 \forall i$. The second alternative hypothesis is called the grouped statistics test (between-dimension), which is based on the heterogeneous property of $\rho_{i}$, i.e., $H_{1}: \rho_{i}<1 \forall i$. 


\section{Kelikume \& Muritala}

\section{RESULTS}

-Unit Root Result

Two-panel unit root tests are used to account for the level of integration of the variables, in both level and first difference. Specifically, the study made use of the Im, Pesaran and Shin (IPS) and the ADFFisher panel unit root tests, which are presented in Table 2. The IPS result shows that the study variables: stock returns (SR), oil price (OP), economic growth rate (RGDPG) and exchange rate (EXC), are non-stationary in levels. However, stationarity in the variables is achieved in the first difference. The result is consistent with models with intercept, and with intercept and trends. The conclusion of the IPS test is also supported by the ADF-Fisher's result, which indicates that all the variables are first differenced stationary. Hence, the study variables are I (1) series.

\begin{tabular}{|c|c|c|c|c|}
\hline Variables & Level & & First Difference & \\
\hline & Intercept & $\begin{array}{l}\text { Intercept and } \\
\text { trend }\end{array}$ & Intercept & Intercept and trend \\
\hline \multicolumn{5}{|c|}{ Im, Pesaran and Shin W-Stat } \\
\hline SR & $-0.7741(0.2194)$ & $-0.3119(0.3776)$ & $-15.3620(0.0000)^{*}$ & $-15.0690(0.0000)^{*}$ \\
\hline $\mathrm{OP}$ & $1.1147(0.8675)$ & $-0.5996(0.2744)$ & $-8.8921(0.0000)^{*}$ & $-8.7118(0.0000)^{*}$ \\
\hline EXC & $5.3024(1.0000)$ & $-0.5035(0.3073)$ & $-12.8875(0.0000)^{*}$ & $-12.9141(0.0000)^{*}$ \\
\hline \multicolumn{5}{|c|}{ ADF-Fisher Chi-Square } \\
\hline SR & $14.9876(0.1325)$ & $14.9393(0.1343)$ & $141.772(0.0000)^{*}$ & $134.613(0.0000)^{*}$ \\
\hline OP & $3.3459(0.9721)$ & $9.6120(0.4752)$ & $92.8111(0.0000)^{*}$ & $82.8998(0.0000)^{*}$ \\
\hline EXC & $0.2765(1.0000)$ & $9.6500(0.4717)$ & $91.9471(0.0000)^{*}$ & $85.2844(0.0000)^{*}$ \\
\hline
\end{tabular}

Table 2. Panel Unit Root Result (IPS and ADF-Fisher)

\section{-Cointegration Result}

Having examined the stationarity properties of the variables, the study investigates the long-run relationship properties of the series using Pedroni panel cointegration test (Table 3). For both withindimension and the between-dimension, the study could reject the null hypothesis of no cointegration, and thus implying that stock returns, oil price and exchange rate have a long-run relationship. As this 
study indicates, even though the properties of the study variables have some measures of a unit root in their levels, a co-movement and convergence to long-run equilibrium are achieved.

\begin{tabular}{lcc}
\hline & Statistics & Prob. \\
\hline \multicolumn{2}{l}{ Alternative Hypothesis: Common AR Coefficients (within-dimension) } \\
\hline Panel v-statistic & -1.3326 & 0.9087 \\
Panel rho-Statistic & -6.0255 & $0.0000^{*}$ \\
Panel PP-Statistics & -10.9398 & $0.0000^{*}$ \\
Panel ADF-Statistic & -7.4411 & $0.0000^{*}$ \\
Alternative Hypothesis: Individual AR Coefficients (Between-dimension) & $0.0000^{*}$ \\
Group rho-Statistics & -5.2202 & $0.0000^{*}$ \\
Group PP-Statistic & -10.9299 & $0.0000^{*}$ \\
Group ADF-Statistic & -6.6066 & \\
\hline Source: Calculated for this study using Eviews & \\
*Significant at 1\% &
\end{tabular}

Table 3. Pedroni Panel Cointegration

\section{-Panel Regression Estimates}

The study provides estimates of both long-run and the short-run panel models, with the study variables in their natural log form. For the long-run analysis, the study employs panel ordinary least square (OLS) and panel dynamic ordinary least square (DOLS). Our results are shown in Tables 4, 5 and 6 (see Appendix-III, IV, V). The long run-result in Table 4 shows that both the fixed effect and random effect estimates give the same relational impacts of oil price and real gross domestic product growth rate on stock returns, although with slight differences in parameters. While for exchange rate, the rational impacts are different-positive under the random effects and negative under the fixed effects. These are achieved at 5 percent level of significance according to the $f$-Statistic. Also, the Hausman test (test summary: Cross-section random; Chi-Sq. Statistic $=6.229505, d f=3$, prob $=$ 0.1010) affirmed the rejection of the null hypothesis i.e., the fixed effects model is more appropriate. Thus, we accepted the alternative hypothesis that the random effects model is more appropriate. Following the estimates provided by the random effects, oil price has a negative impact on stock returns, however, not significant. The effect on stock is approximately 0.09 percent when the oil prices 


\section{Kelikume \& Muritala}

change by 1 percent. However, real gross domestic product growth (RGDPG) rate has a significant positive impact on stock returns as shown by the result of the cointegration regression and affirmed by the estimated random effects model. Based on the random effect estimation, the stock market returns improve by approximately 0.44 percent when RGDP growth rate increases by 1 percent. Our finding is consistent with (Diaz et al., 2016; Jain and Biswal, 2016; Møller and Rangvid, 2015) which reported that oil price fluctuations adversely affect stock returns. However, our results do not support the position of Narayan and Narayan (2010), Papapetrou (2001), Ghosh and Kanjilal (2016), and Chen and Lu (2015) that found a positive impact of oil price on stock returns. In addition, the result shows that exchange rate has a significant adverse effect on stock returns in the long-run as shown in Table 4 and 5.

Table 6 presents our results from the short run DOLS (see Appendix-V). As the results indicate, there is no statistically significant effect of oil price on stock market returns. Similarly, exchange rate shows no significant impact on stock market returns, even though the two variables exhibit some level of negative and weak positive relationship. The insignificant effect of the study variables in the short run can be attributed to the fact that it takes more than a short period, one quarter month in this case, for any changes in oil price and exchange rate to have a significant effect, unlike in the long run when reactions will have matured. The coefficient of error correction term (ECT) point to the fact that up to 65 percent in the stock adjustment in the stock market can be achieved a quarter following shocks in the system.

\section{CONCLUSION}

This study deploys the use of quarterly data spanning Q1:2010 till Q4:2018 6 to examine the impact of oil price, exchange rate and RGDP growth on stock market returns in five oil-exporting African nations, namely Nigeria, Egypt, South Africa, Tunisia, and Ghana. Employing the Im, Pesaran and Shin (IPS) and the ADF-Fisher Unit root tests revealed that the variables are integrated in their first order, I (1). The Pedroni panel cointegration tests further disclose the existence of a long-run relationship among the variables.

Both the Panel OLS and the panel dynamic OLS results give the same conclusion and confirm that the stock market returns of the study countries are negatively and positively affected by the international crude oil price and RGDP growth respectively, while exchange rate recorded mixed impacts. The non-significant nature of oil price implies that there are other variables that have to be considered in the African settings to boast the stock market. This may not be unconnected with the cyclical trends experienced in the global oil price often driven by demand and supply dynamics. The 
International Journal of Management, Economics and Social Sciences

RGDPG points to a significant positive effect on stock returns. The significant positive effect is expected as the capital markets of oil-exporting developing countries gain from the aggregate demand boast during favorable oil market. In the same way, a negative windfall in the international price of crude oil will negatively affect the capital market of oil-exporting developing nations via shrinking economic growth rate.

\section{IMPLICATIONS}

Our results show that the effect of oil price on stock markets is not significant. However, real growth has a positive impact on stock markets. The findings point to how the performance of the capital market of oil-exporting developing nations is tied to the behavior of global commodity markets through the economic growth mechanism. An expansion in economic activities leads to a bullish stock market with benefits for active stock market players. The African nations in the study are oil exporting nations; an increase in the price of crude oil in the international market invariably increases the nation's income level. It also transmits positively to boost the government's expenditure, thus providing enabling economic and investment environments for businesses. In the long-run, this helps to fuel the real sector and industries at large and subsequently reflects in the stock market performance/returns. This pathway communicates the oil price volatility negative impact on stock returns in oil the exporting nations. The examined African countries have over the years experienced exchange rate volatility with Nigeria as the worst hit. Volatility in exchange rate produces two pass-through effects, namely transaction and translation risks, which cause capital flight and subsequently shrinking stock returns.

To some great extents, the financial sector is under the control of international oil price and exchange rate markets, which are outside the grasp of the nation's policymakers. Given the critical role of the financial sector in an economy, also the significant role played by the capital market in the industry, it should be a top priority for oil-exporting developing nations to devise control and strategies that can ensure stability in the capital market irrespective of shocks in oil price and other exogenous macroeconomic variables. This study establishes the need for capital market investors and fund managers to diversify their portfolio for effective risk management and 'shock' hedging.

\section{LIMITATIONS AND FUTURE DIRECTIONS}

The major limitation of the current study rests in the fact that, because of the lack of stock market data in African countries, only five of the major oil exporting countries in Africa are examined. Thus, the policy implications may not effectively apply to other African countries outside the scope of this article. Also, the scanty number of theories on oil-stock space limits the extent to which this study 


\section{Kelikume \& Muritala}

could be theoretically validated. It will be interesting for future research to explore the effects of oil price on stock returns in both oil-exporting and import-dependent countries in Africa. Future studies should observe the effect of structural breaks due to friction, including regulatory constraints and exogenous factors that may yield variation in rates of adjustment. Finally, future studies should probe into other macroeconomic and environmental factors-firms' competitiveness, government regulation and market openness that affect stock market performance.

\section{REFERENCES}

An, Y., Sun, M., Gao, C., Han, D. \& Li, X. (2018). Analysis of the impact of crude oil price fluctuations on China's stock market in different periods-Based on time series network model. Physica A: Statistical Mechanics and its Applications, 492, 10161031.

Al-hajj, E., Al-Mulali, U. \& Solarin, S. A. (2018). Oil price shocks and stock returns nexus for Malaysia: Fresh evidence from nonlinear ARDL test. Energy Reports, 4, 624-637.

Al-Mulali, U. \& Sab, C. N. B. C. (2012). The impact of energy consumption and CO2 emission on the economic growth and financial development in the Sub Saharan African countries. Energy, 39(1): 180-186.

Arouri, M. E. H. \& Rault, C. (2009). On the influence of oil prices on stock markets: Evidence from panel analysis in GCC countries. CESifo Working Paper, No. 2690.

Arouri, M. E. H., Jouini, J. \& Nguyen, D. K. (2012). On the impacts of oil price fluctuations on European equity markets: Volatility spillover and hedging effectiveness. Energy Economics, 34(2): 611-617.

Asaolu, T. O. \& Ilo, B. M. (2012). The Nigerian stock market and oil price: A cointegration analysis. Arabian Journal of Business and Management Review, 33(834): 1-16.

Aye, G. C. (2014). Does oil price uncertainty matter for stock returns in South Africa? Investment Management and Financial Innovations, 12(1-1): 179- 188

Badeeb, R. A. \& Lean, H. H. (2018). Asymmetric impact of oil price on Islamic sectoral stocks. Energy Economics, 71, 128139.

Basher, S. A., Haug, A. A. \& Sadorsky, P. (2018). The impact of oil-market shocks on stock returns in major oil-exporting countries. Journal of International Money and Finance, 86, 264-280.

Bastianin, A. \& Manera, M. (2018). How does stock market volatility react to oil price shocks? Macroeconomic Dynamics, 22(3): 666-682.

Burbidge, J. \& Harrison, A. (1984). Testing for the effects of oil-price rises using vector autoregressions. International Economic Review, 25(2): 459-484.

Diaz, E. M., Molero, J. C. \& de Gracia, F. P. (2016). Oil price volatility and stock returns in the G7 economies. Energy Economics, 54, 417-430.

Ding, Z., Liu, Z., Zhang, Y. \& Long, R. (2017). The contagion effect of international crude oil price fluctuations on Chinese stock market investor sentiment. Applied Energy, 187, 27-36.

Dutta, A., Nikkinen, J. \& Rothovius, T. (2017). Impact of oil price uncertainty on Middle East and African stock markets. Energy, 123, 189-197.

Ewing, B. T. \& Thompson, M. A. (2018). Modeling the Response of Gasoline-Crude Oil Price Crack Spread Macroeconomic Shocks. Atlantic Economic Journal, 46(2): 203-213.

Ftiti, Z., Guesmi, K. \& Abid, I. (2016). Oil price and stock market co-movement: What can we learn from time-scale approaches? International Review of Financial Analysis, 46, 266-280.

Ghosh, S. \& Kanjilal, K. (2016). Co-movement of international crude oil price and Indian stock market: Evidences from nonlinear cointegration tests. Energy Economics, 53, 111-117.

Gil-Alana, L. A. \& Yaya, O. S. (2014). The relationship between oil prices and the Nigerian stock market. An analysis based on fractional integration and cointegration. Energy Economics, 46, 328-333.

Gisser, M. \& Goodwin, T. H. (1986). Crude oil and the macroeconomy: Tests of some popular notions: Note. Journal of Money, Credit and Banking, 18(1): 95-103.

Gourène, G. A. Z. \& Mendy, P. (2018). Oil prices and African stock markets co-movement: A time and frequency analysis. Journal of African Trade, 5(1-2): 55-67.

Gupta, R. \& Modise, M. P. (2013). Does the source of oil price shocks matter for South African stock returns? A structural VAR approach. Energy Economics, 40, 825-831.

Hamdi, B., Aloui, M., Alqahtani, F. \& Tiwari, A. (2019). Relationship between the oil price volatility and sectoral stock markets in oil-exporting economies: Evidence from wavelet nonlinear denoised based quantile and Granger-causality analysis. Energy Economics, 80, 536-552.

Hamilton, J. D. (1983). Oil and the macroeconomy since World War II. Journal of Political Economy, 91(2): 228-248.

He, T. X. \& Nguyen, T. (2015). Wavelet analysis and applications in economics and finance. Journal of Statistics and Mathematical Sciences, 1(1): 22-37. 
Herwartz, H. \& Plödt, M. (2016). The macroeconomic effects of oil price shocks: Evidence from a statistical identification approach. Journal of International Money and Finance, 61, 30-44.

Hu, C., Liu, X., Pan, B., Chen, B. \& Xia, X. (2018). Asymmetric impact of oil price shock on stock market in China: A combination analysis based on SVAR model and NARDL model. Emerging Markets Finance and Trade, 54(8): $1693-1705$.

Huang, S., An, H., Gao, X. \& Sun, X. (2017). Do oil price asymmetric effects on the stock market persist in multiple time horizons? Applied Energy, 185, 1799-1808.

Huntington, H. G. (2007). Oil shocks and real US income. The Energy Journal, 28(4): 31-46.

IEA. (2016). The International Energy Agency-World energy outlook. Retrieved on January 18, 2019 from https://www.iea.org /news room /news/2016/november/world-energy-outlook-2016.html.

Jain, A. \& Biswal, P. C. (2016). Dynamic linkages among oil price, gold price, exchange rate, and stock market in India. Resources Policy, 49, 179-185.

Jammazi, R. (2012). Oil shock transmission to stock market returns: Wavelet-multivariate Markov switching GARCH approach. Energy, 37(1): 430-454.

Ji, Q., Liu, B. Y., Zhao, W. L. \& Fan, Y. (2018). Modelling dynamic dependence and risk spillover between all oil price shocks and stock market returns in the BRICS. International Review of Financial Analysis, doi:10.1016/j.irfa.2018.08.002.

Ju, K., Su, B., Zhou, D., Wu, J. \& Liu, L. (2016). Macroeconomic performance of oil price shocks: Outlier evidence from nineteen major oil-related countries/regions. Energy Economics, 60, 325-332.

Kang, W., de Gracia, F. P. \& Ratti, R. A. (2017). Oil price shocks, policy uncertainty, and stock returns of oil and gas corporations. Journal of International Money and Finance, 70, 344-359.

Kilian, L. (2008). Exogenous oil supply shocks: how big are they and how much do they matter for the US economy? The Review of Economics and Statistics, 90(2): 216-240.

Kumar, B. C. \& Goh, A. H. Y. (2019). Macroeconomic Factors and Stock Price in Malaysia. Economics, Finance, Business and Management, 1(1): 2-7.

Lee, K., Ni, S. \& Ratti, R. A. (1995). Oil shocks and the macroeconomy: the role of price variability. The Energy Journal, 16 , 39-56.

Lin, B., Wesseh, P. K. \& Appiah, M. O. (2014). Oil price fluctuation, volatility spillover and the Ghanaian equity market: Implication for portfolio management and hedging effectiveness. Energy Economics, 42, 172-182.

Luo, X. \& Qin, S. (2017). Oil price uncertainty and Chinese stock returns: New evidence from the oil volatility index. Finance Research Letters, 20, 29-34.

Mendoza, O. \& Vera, D. (2010). The asymmetric effects of oil shocks on an oil-exporting economy. Cuadernos de economía, 47(135): 3-13.

Mikhaylov, A. Y. (2018). Pricing in oil market and using probit model for analysis of stock market effects. International Journal of Energy Economics and Policy, 8(2): 69-73.

Mork, K.A (1997). Oil and Macroeconomy When Prices Go Up and Down: An Extension of Hamilton's Results. Journal of Political Economy, 97(3):740-44.

Møller, S. V. \& Rangvid, J. (2015). End-of-the-year economic growth and time-varying expected returns. Journal of Financial Economics, 115(1): 136-154.

Narayan, P. K. \& Narayan, S. (2010). Modelling the impact of oil prices on Vietnam's stock prices. Applied Energy, 87(1): 356361.

Ono, S. (2011). Oil price shocks and stock markets in BRICs. The European Journal of Comparative Economics, 8(1): 29-45.

Pal, D. \& Mitra, S. K. (2019). Oil price and automobile stock return co-movement: A wavelet coherence analysis. Economic Modelling, 76, 172-181.

Panda, A. K., Nanda, S. \& Paital, R. R. (2019). An empirical analysis of stock market interdependence and volatility spillover in the stock markets of Africa and Middle East region. African Journal of Economic and Management Studies. Available at: https://doi.org/10.1108/AJEMS-10-2018-0293.

Papapetrou, E. (2001). Oil price shocks, stock market, economic activity and employment in Greece. Energy Economics, 23(5): 511-532.

Rafailidis, P. \& Katrakilidis, C. (2014). The relationship between oil prices and stock prices: a nonlinear asymmetric cointegration approach. Applied Financial Economics, 24(12): 793-800.

Ratti, R. A. \& Vespignani, J. L. (2016). Oil prices and global factor macroeconomic variables. Energy Economics, 59, 198212.

Raymond, J.E \& Rich, R (1997). Oil and the Macroeconomy: A Markov State-Switching Approach. Journal of Money, Credit and Banking, 29(2): 193-213.

Salisu, A. A. \& Oloko, T. F. (2015). Modeling oil price- US stock nexus: A VARMA- BEKK- AGARCH approach. Energy Economics, 50, 1-12.

Sharma, A., Giri, S., Vardhan, H., Surange, S., Shetty, R. \& Shetty, V. (2018). Relationship between crude oil prices and stock market: Evidence from India. International Journal of Energy Economics and Policy, 8(4): 331-337.

Shahbaz, M., Nasreen, S., Abbas, F. \& Anis, O. (2015). Does foreign direct investment impede environmental quality in high-, middle-, and low-income countries? Energy Economics, 51, 275-287.

Singhal, S., Choudhary, S. \& Biswal, P. C. (2019). Return and volatility linkages among International crude oil price, gold price, exchange rate and stock markets: Evidence from Mexico. Resources Policy, 60, 255-261.

Soyemi, K. A., Akingunola, R. O. O. \& Ogebe, J. (2017). Effects of oil price shock on stock returns of energy firms in Nigeria. Kasetsart Journal of Social Sciences, Retrieved on January 22, 2019 from https://www.sciencedirect.com/science/article/pii/S2452315117301352.

Sadorsky, P. (1999). Oil price shocks and stock market activity. Energy Economics, 21 (5): 449-469. 


\section{Kelikume \& Muritala}

Tursoy, T. \& Faisal, F. (2018). The impact of gold and crude oil prices on stock market in Turkey: Empirical evidences from ARDL bounds test and combined cointegration. Resources Policy, 55, 49-54.

Wei, Y. \& Guo, X. (2017). Oil price shocks and China's stock market. Energy, 140, 185-197.

Wong, V. S. \& El-Massah, S. (2018). Recent Evidence on the Oil Price Shocks on Gulf Cooperation Council Stock Markets. International Journal of the Economics of Business, 25(2): 297-312.

Xiao, J., Zhou, M., Wen, F. \& Wen, F. (2018). Asymmetric impacts of oil price uncertainty on Chinese stock returns under different market conditions: Evidence from oil volatility index. Energy Economics, 74, 777-786.

Zhu, H. M., Li, S. F. \& Yu, K. (2011). Crude oil shocks and stock markets: A panel threshold cointegration approach. Energy Economics, 33(5): 987-994.

Zhu, H., Guo, Y., You, W. \& Xu, Y. (2016). The heterogeneity dependence between crude oil price changes and industry stock market returns in China: Evidence from a quantile regression approach. Energy Economics, 55, 30-41. 
Appendix-I

\begin{tabular}{|c|c|c|c|c|c|c|c|c|}
\hline Variable & Country & $\mathbf{N}$ & Range & Minimum & Maximum & Mean & $\begin{array}{c}\text { Std. } \\
\text { Error. }\end{array}$ & $\begin{array}{c}\text { Std. } \\
\text { Deviation }\end{array}$ \\
\hline \multirow[b]{5}{*}{ Stock returns } & Nigeria & 36 & 15.784 & -6.541 & 9.244 & .526 & .147 & 3.662 \\
\hline & Egypt & 36 & 24.109 & -7.451 & 16.658 & .999 & .188 & 5.084 \\
\hline & $\begin{array}{l}\text { South } \\
\text { Africa }\end{array}$ & 36 & 7.013 & -2.953 & 4.060 & .713 & .087 & .752 \\
\hline & Tunisia & 36 & 9.517 & -4.560 & 4.957 & .487 & .0620 & 2.166 \\
\hline & Ghana & 36 & 41.282 & -28.111 & 13.171 & .475 & .013 & 6.201 \\
\hline \multirow[b]{5}{*}{ Oil price } & Nigeria & 36 & 86.44 & 31.190 & 117.630 & 78.788 & 3.129 & 26.804 \\
\hline & Egypt & 36 & 86.44 & 31.190 & 117.630 & 78.788 & 3.129 & 26.804 \\
\hline & $\begin{array}{l}\text { South } \\
\text { Africa }\end{array}$ & 36 & 86.44 & 31.190 & 117.630 & 78.788 & 3.129 & 26.804 \\
\hline & Tunisia & 36 & 86.44 & 31.190 & 117.630 & 78.788 & 3.129 & 26.804 \\
\hline & Ghana & 36 & 86.44 & 31.190 & 117.630 & 78.788 & 3.129 & 26.804 \\
\hline \multirow[b]{5}{*}{ GDP growth } & Nigeria & 36 & 11.313 & -1.941 & 9.372 & 3.808 & .062 & 3.046 \\
\hline & Egypt & 36 & 5.920 & 1.337 & 7.257 & 3.651 & .095 & 1.478 \\
\hline & $\begin{array}{l}\text { South } \\
\text { Africa }\end{array}$ & 36 & 2.881 & .517 & 3.398 & 2.026 & .087 & .855 \\
\hline & Tunisia & 36 & 10.329 & -2.302 & 8.027 & 2.050 & .295 & 2.031 \\
\hline & Ghana & 36 & 12.425 & 2.050 & 14.475 & 6.891 & .188 & 4.784 \\
\hline \multirow{5}{*}{$\begin{array}{c}\text { Exchange } \\
\text { rate }\end{array}$} & Nigeria & 36 & 156.616 & 150.097 & 306.713 & 203.930 & 1.959 & 16.850 \\
\hline & Egypt & 36 & 12.450 & 5.583 & 18.033 & 9.430 & .096 & 4.768 \\
\hline & $\begin{array}{l}\text { South } \\
\text { Africa }\end{array}$ & 36 & 9.040 & 6.803 & 15.843 & 10.817 & .295 & 2.773 \\
\hline & Tunisia & 36 & 1.534 & 1.373 & 2.907 & 1.880 & .024 & .430 \\
\hline & Ghana & 36 & 3.367 & 1.430 & 4.797 & 2.908 & .106 & 1.216 \\
\hline
\end{tabular}

Table 1. Descriptive Statistics 
Kelikume \& Muritala

Appendix-II

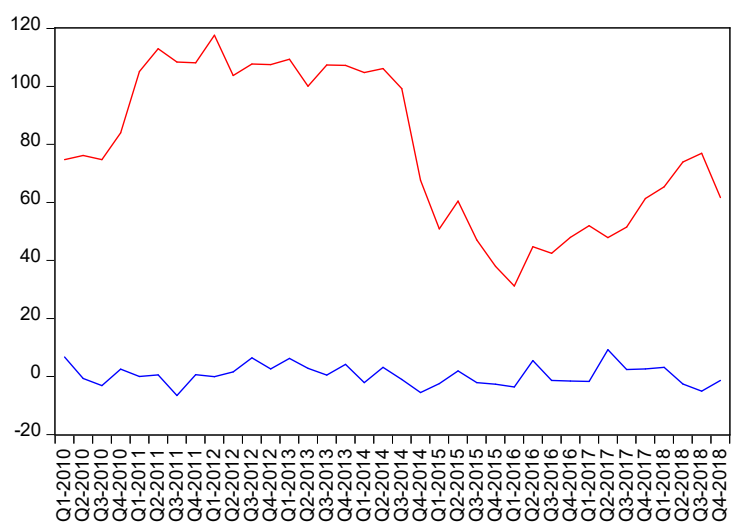

$-\mathrm{SR}-\mathrm{OP}$

Source: Plotted using Eviews for this study

Figure 1. Movement in Oil Prices and Stock Prices in Nigeria

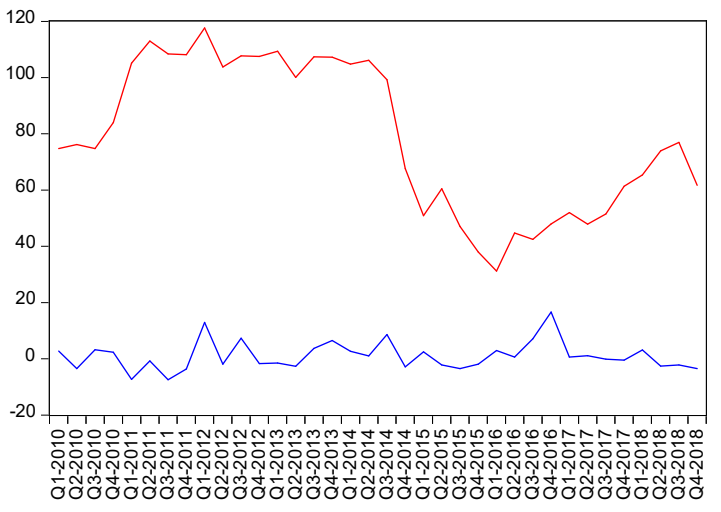

$-\mathrm{SR}-\mathrm{OP}$

Source: Plotted using Eviews for this study

Figure 2. Movement in Oil Prices and Stock Prices in Egypt 

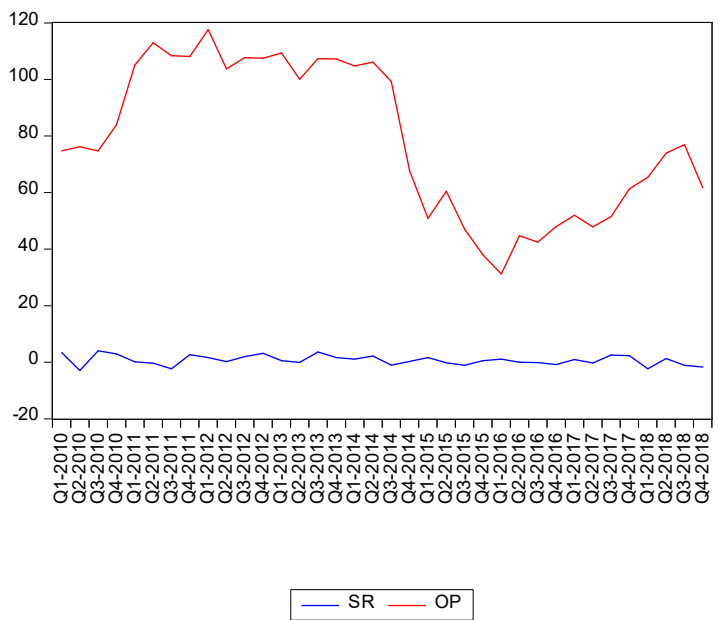

Source: Plotted using Eviews for this study

Figure 3. Movement in Oil Prices and Stock Prices in South Africa
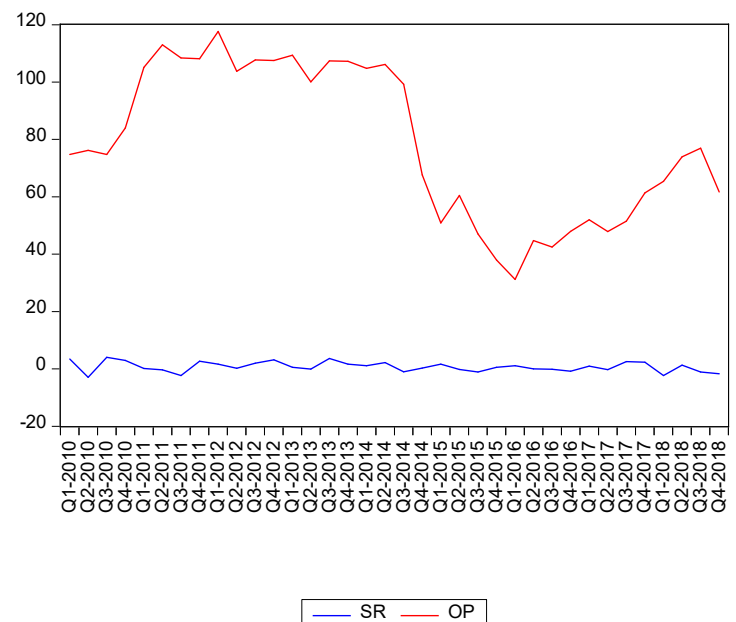

Source: Plotted using Eviews for this study

Figure 4. Movement in Oil Prices and Stock Prices in Tunisia 
Kelikume \& Muritala

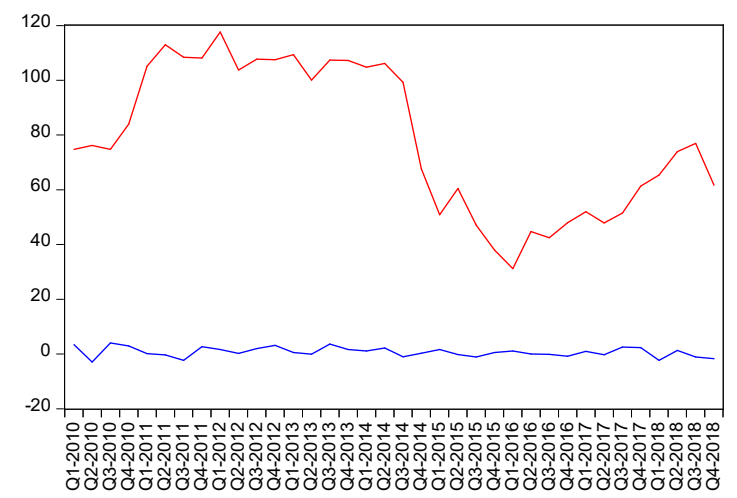

$-\mathrm{SR}-\mathrm{OP}$

Source: Plotted using Eviews for this study

Figure 5. Movement in Oil Prices and Stock Prices in Ghana 


\begin{tabular}{lll}
\hline Dependent Variable: $L S P$ & \\
\hline & Fixed Effects & Random Effects \\
\hline CONSTANT & $2.0021(0.4778)$ & $0.2567(0.8697)$ \\
LNOP & $-0.1523(0.7519)$ & $-0.0904(0.8112)$ \\
LNEXC & $-0.1100(0.4496)$ & $0.0895(0.2664)$ \\
LNRGDPG & $0.1212(0.6528)$ & $0.4359(0.0285)^{*}$ \\
Observation & 180 & 180 \\
Hausman Test & & $6.2295(0.1010)$ \\
F-Stat & $2.055(0.0564)^{* *}$ & $2.0340(0.1143)$ \\
\hline
\end{tabular}

Source: Calculated for this study using Eviews

*Significant at 1\%; ** Significant at $10 \%$

Table 4. Panel Least Square Result 
Kelikume \& Muritala

Appendix-IV

\begin{tabular}{lllll}
\hline \multicolumn{4}{l}{ Dependent Variable: } & LNSP \\
& Coefficient & Standard Error & $\boldsymbol{t}$-statistics & Prob. \\
\hline LNOP & -4.6795 & 3.8787 & -1.2064 & 0.2374 \\
LNEXC & -64.1238 & 3.9995 & -16.0328 & $0.0000^{*}$ \\
LNRGDPG & 39.0215 & 3.6236 & 10.7687 & $0.0000^{*}$ \\
\hline $\begin{array}{l}\text { Source: Calculated for this study using Eviews } \\
\text { *Significant at 1\% }\end{array}$ & & & & \\
\end{tabular}

Table 5. Panel Least Square Result 


\begin{tabular}{|c|c|c|c|c|}
\hline \multicolumn{5}{|c|}{ Dependent Variable: $D(L S P)$} \\
\hline & Coefficient & Standard Error & $t$-statistics & Prob. \\
\hline CONSTANT & 0.2882 & 1.5849 & 0.1819 & 0.8561 \\
\hline$D(L O P)$ & -0.1015 & 0.3837 & -0.2647 & 0.7918 \\
\hline$D($ LEXC $)$ & 0.0907 & 0.0792 & 1.1448 & 0.2552 \\
\hline$D(L N R G D P G)$ & 0.4466 & 0.1964 & 2.2744 & 0.0252 \\
\hline$E C T(-1)$ & -0.6590 & 0.0167 & -6.4652 & $0.0000^{*}$ \\
\hline$F-S t a t$ & $2.1876(0.0945)^{* *}$ & & & \\
\hline
\end{tabular}

Table 6. Short-Run Result 